\title{
Computer education: a medium for sustainable development and human capacity building in Nigeria
}

\author{
Maharazu Mamman \\ Department of Computer Science, Federal College of Education, Katsina, Katsina State, Nigeria
}

\begin{abstract}
Computer education is one of the main keys to economic development and improvements in human welfare. As global economic competition grows sharper, Computer education becomes an important source of competitive advantage, closely linked to economic growth, and a way for countries to attract jobs and investment. In addition, Computer education appears to be one of the key determinants of lifetime earnings. Countries therefore frequently see raising Computer educational attainment as a way of tackling poverty and deprivation. In developing countries, Computer education is also linked to a whole batch of indicators of human development. The experience of Nigerian economies in particular in the past two decades has demonstrated the benefits that public investment in Computer education can bring. The responsibility of this paper therefore, is to discuss the integration Computer education in teacher education for capacity building and sustainable development. Areas of concern are integration of Computer education in teacher education for capacity building and sustainable development, challenges of Computer education in teacher education, and approaches to Computer education integration. The paper concludes and recommends how to build human resources that will build the nation and bring sustainable development Computer education must be integrated into teacher education and Computer education should be a compulsory subject or course for all students in teacher training institutions.
\end{abstract}

Keywords: Computer education; human capacity building; sustainable development; integration; teacher education

\section{INTRODUCTION}

Nigeria is a great nation full of human and natural resources which have been long underutilized due to ignorance and illiteracy. No country can fully develop except these problems that are ignorance and illiteracy are completely dealt with. That is why one of the main goal or emphasis of developing nation is education. In addition the Millennium development goals and vision 20:2020 all emphasize on education.

According to Bulus I., and Mai A., (2006) "Education can be seen as an exercise externally concerned with guidance of man in a way that result in as much achievement of the good life as possible". We are thinking more about that way of living relating condition, conduct and occupations of and between man and his society.

If everyone is properly educated, crimes and other social vices will reduce. Education can also be seen as the transfer of norms, values, culture and morals from one generation to another. Over the years education has contributed immensely to the development of Nigeria as 
nation. This is clearly seen from our heroes who first acquire education and thereafter fought for our independence. They also pave way for their follower get education.

Presently in the world, critical examination show that thought schools have multiplied, yet many are still denied their right to education. Worst still many who claimed to be educated are actually not as clearly shown from their behavior and actions, this is because education has not been properly delivered. Therefore Computer education can make a difference. Computers have basic qualities that have transformed various sectors of our economy as can be seen in the banks, immigration, crime fighting, agriculture, commerce and medical. In today's society rapid technological changes and the new variety of communication media will accelerate the rate at which computer education when embraced thereby promoting human capacity building and sustainability.

\section{MOTIVATIONS AND SIGNIFICANT OF THE STUDY}

A lot of advantages will be obtained based on this research paper to the educational sector in Nigeria and above all to the nation capacity building and sustainability. It will also save as the Nigerian educators as a source of referencing if accepted and implemented.

The importance of the study to Nigerian society is tremendous. It will make a great impact on our national pride, social tolerance, political stability, nation building, sustainable development and economics as a whole.

\section{CONTRIBUTION TO THE KNOWLEDGE}

This study was necessitated as Nigerian government in order to have human capacity building and attain sustainable development Computer education is a pre-requisite, therefore the main contribution to this work is that students, staff and researchers will use the article as a focal point and as a start approach to see how to use Computer education as a medium for human capacity building and sustainable development.

\section{EDUCATION AS A SOURCE OF HUMAN CAPACITY BUILDING AND SUSTAINABLE DEVELOPMENT}

Bulus, I. and Mai, I., (2006) stated that "Education described the total process of human learning by which knowledge is imparted, faculties trained and skills development". According to Okoro (2010) "Education may be conceptualized as all efforts, conscious and direct, incidental and indirect, made by a given society to accomplish certain objectives that are considered desirable in terms of individual's own need as well as the need of the society where that education is based. It is a process by which every society attempt to preserve and upgrade the accumulated knowledge, skill and attitude in its cultural setting and heritage in order to foster continuously the well being of mankind and to guarantee its survival against the unpredictable, at times hostile and destructive, elements and forces of nature (Okoro, 2010).

Though education concept does not lend itself easily to definition yet it can always be linked to development. The essence of pursing development is to improve human life. Okoro (2010) stated that "the world bank report in 1991 assert that the challenges of development is to improve the quality of human life". 


\section{HISTORICAL CONTEXT OF CHALLENGE OF SUSTAINABLE DEVELOPMENT}

The Brundtland definition of sustainable development as "development that meets the needs of the present without compromising the ability of future generations to meet their own needs" remains as good today as when it was first drafted in 1987. What it means is that we have to deliver better economic opportunities to eight billion or more people without collapsing the ecological foundations of the economy. That is precisely those systems - the oceans, forests, freshwaters and climate - that it will take success at the hard politics of the environment to protect.

We forget too easily that these systems provide everything in our economy that is not provided by fossil fuels and non-fossil minerals. Sustainable development is not about balancing anything. It does not mean striking some lowest common denominator equilibrium between environmental, social and economic factors. It is about maintaining the basic environmental conditions without which economic development cannot take place at all. Indeed, in the case of the climate, it is about maintaining the fundamental environmental conditions for civilization itself.

In the nineteenth Century we learned the hard way that you must maintain the social conditions for economic growth or your economy will not grow. It took until the middle of the twentieth Century for everyone to accept the need to invest some of the proceeds of economic growth in maintaining those social conditions health, education, welfare. But by then we had spent five decades deciding whether communism or fascism was our preferred form of totalitarianism. It took another four decades before both options in that grim choice were finally gone (Adam 2006).

If we fail to maintain the environmental conditions for development, if we do not invest much more of the proceeds of that development in their maintenance, if, in other words, we do not make the transition to sustainable development, we will repeat that sad lesson in this century and the consequences of that failure will be even more catastrophic for humanity (Otta 2003).

\section{INTEGRATION COMPUTER EDUCATION FOR HUMAN CAPACITY BUILDING AND SUSTAINABLE DEVELOPMENT}

Capacity building is the equipping of the human resources with skills and knowledge that will enable them increases their productivity. Teacher capacity building therefore, is the training of teachers as to equip them with the skills and knowledge required for enhancing of their teaching output. Capacity building for teachers through Computer education will enable and equip teachers that are ill-equipped in the use of Computer tools for teaching and learning to be able to do so. The integration process will entail planning, curriculum review patterned to suit Computer integration, development of software that is compatible with the curriculum designed, training of curriculum experts, training of Computer education resource person's, training of lecturers in teacher training institutes in the use of Computer education, creation of awareness to all the stakeholders of education.

The first step to take for successful integration of Computer education in teacher education is the critical examination and assessment of the teacher training institutions (Agabi, 2008). Policy planners must assess the activities of the institution, if required facilities are available; ascertain their staff strength, staff qualifications, number of students the Computer education equipment present can accommodate, and other necessary information. 
Also to be ascertained is what the institution seeks to achieve and efforts made to achieving them. This will be done because the school personnel (academics and non-academic) will be used, ascertaining this will determine the extent to which the aim of the programme can be achieved. In other words, the vision of the institution must be known. To ascertain as well is the course and various discipline covered $b$ y the institution. The course contents have to be evaluated if it can accommodate Computer education Computer education integration and if it is such that can equip the students and teacher to be able to face the challenges in the discharge of the duties. Methods used in teaching and learning are also important to be verified.

This will be done to know how relevant the teaching methods used can be compatible with the technology to be introduced, if the method(s) are suitable for Computer education. If found otherwise, it is important that teachers in these school be equipped with Computer education skills and knowledge used in teaching and learning. This is because if they are, they can be used as resource persons in the instruction of Computer education use in teaching and learning. Moreover, the extent of the institutions achievement or their level of contribution to the development of the individual, society and the nation at large will be considered. It will involve ascertaining outstanding achievement records, in terms of school achievement, achievement of staff and students.

Curriculum Development: Secondly, teacher training curriculum as to $b$ e reviewed by curriculum designers. This process will be done to ascertain if the curriculum is suitable to achieve the desired result. If not, it will be restructured in a way that the outcome of the Computer education integration will solve the problem it is aimed at solving.

ICT Software Development: Instructional aid designers and computer software designers have to work together to development software's that will be compatible with Computer education to be introduced. This is because, teacher ability to link technology and curriculum is important in attending effective Computer education integration. Teachers must be able to appreciate and see the usefulness of Computer education use in their everyday work. So, development of Computer education software's that will be compatible with the curriculum is important. This must be developed in a way that teachers can interpret and apply same in the teaching and learning process. This task is quite enormous and challenging therefore, workshops for school heads and teachers on how curriculum can be used with Computer education tools and the importance of using Computer education in teaching and learning must be done.

Funding: Oil companies and Non-governmental organizations (NGO) that contribute to the development of the nation has role to play in achieving this venture. They can contribute their quota by donating computers to teacher training institutions and schools. As well as organize Computer education professional skill training from school heads and teachers. All these had to be done because; it is believed that when teachers perceive Computer education as a tool to meet curriculum goals, they are more likely to integrate Computer education in their lessons. Therefore, to achieve effective Computer education integration in teacher education, training in Computer education must involve skills and knowledge learnt in school setting (classroom) (UNISCO Bangkok 2004, p. 104).

Creation of Awareness: School heads and teachers must be sensitized and trained on the use of Computer education in effective teaching and learning this process can be done on local government bases.

Sensitization and Training for Lecturers in Teaching Institutions: The lecturers to be used as resource persons in the Computer education integration programme must be trained on the 
Computer education tools to be used and how these tools can be used with the curriculum of different discipline and how the knowledge acquired can be transferred to the students.

Incentives and Motivating Environment: Effective Computer education integration also requires introduction of incentives and provision of motivating environment. Every individual like to be motivated to perform better or bring out the best in him. In the same way, teachers require motivation and incentives like allowances, recognition and award of prizes for outstanding performance, creativity and innovativeness. Government and well meaning individual can do this to spur teachers' commitment in the training. Moreover, conducive and motivating environment is important in Computer education integration success. Computer education laboratories must be constructed to be teaching - learning friendly and all facilities needed for the training must be available. Moreover, outstanding students can be made resource assistants to help the resource person's; this will be a strong motivation. In line with the above statement, Carlson and Gadio (2002, p.22) said that to foster an environment that is supportive in learning how to teacher effectively with technology, implementing an incentive system and motivational strategies are important. Because teachers are usually reluctant to change their teaching style. In other words, good number of teachers refuses change; they require additional motivation and incentives to participate actively in professional development activities especially if they have been in the field of teaching for long. The scholar further suggests that these motivation strategies and incentives can be used in successful integration of Computer education in teacher education.

I. Make teachers have access to technology resources. All that is required in the practical aspect of the training must be available. Teachers must have computer in the teacher training institution and in their teaching schools.

II. Make them work in team. Teachers should be made to work in team with their colleagues when solving assignments especially in assignment that has to do with technology instruction support design. Learning in teams will encourage contribution of ideas from different students that will make for clearer understanding of what is taught.

III. Give time and recognize innovation. New knowledge requires time to be understood. Time allowance must be considered during training and innovation from students with outstanding performance in the understanding of new knowledge need to be recognized and rewarded.

Furthermore, teacher capacity building in Computer education must include pedagogical capacity building and capacity building in the use of education technology. Missing out either of them in the training will ill-equip the teachers' and make them incapable in the use of Computer education tools. The training must include training on the use of Computer education tools in effective teaching and learning as well as to equip them with the knowledge and skill to appropriate Computer education tools and instructional aids.

Integration Modalities: Computer education can be integrated into teacher education through pre-service and in-service integration. The process of integrating Computer education in teacher education will be achieved through the various teacher training institutions. The aim is to equip the student's under-taking teacher training course with the knowledge and skills of Computer education before graduation. To realize this, computer education must be integration into the course work and made compulsory for all students. The course should be designed in a way that theory and practical will be involved, but more time will be allocated to the practical 
aspect of the course. The practical should be designed to include both personal and teamwork as this will help create confidence in the use of Computer education and better understanding in the part of the students. Computers, Computer education teachers, Computer education laboratory attendants and technicians must be available to enhance learning.

In-service Computer education training can also be organized for serving teachers as a way of integrating Computer education into the education system. This type of integration will require intensive classes during the holidays and some weekend and should be organized by the existing teacher training institutions, so that their personnel and facilities can be used. This approach will create opportunity for every teacher to partake in the training. Its effectiveness will depend on award of certificate and making it compulsory for all teachers. Course involvement should also include both theory and practical done personally and in groups. Inservice training should go beyond ordinary certificate for attendance. The training should be up to degree for teachers who are willing to bag the degree beside their teacher qualification. Those who choose to continue to degree level should be promoted and elevated and even be used as resource person in the schools.

\section{CHALLENGES OF COMPUTER EDUCATION INTEGRATION IN TEACHER EDUCATION FOR HUMAN CAPACITY BUILDING AND SUSTAINABLE DEVELOPMENT}

Every innovation comes with some challenges that must be handled before any success is achieved. Some of the challenges in the integration of Computer education in teacher education are (Ololube A. C., et al 2006):

a. Accommodation: A major challenge in effective Computer education integration is suitable accommodation in teacher training institutions were the equipment will be kept and use. Where there is none-one has to be built and properly electrified. In case of existing structures, its electrification fitting has to be ascertained, because safety is important.

b. Population: The number of students in the institutions, serving teacher and headteachers are much. Providing all with computers will be quit challenging because of its cost involvement.

c. Power Situation in Nigeria: Adequate power supply to run the equipment is important. Power situation in Nigeria will pose a serious challenge. So alternative (solar or generator) source must be provided.

d. Lack of Computer education skilled manpower (technicians) who will help train the teachers. This caliber of personnel is needed in the maintenance of the equipment. There services are important in success of the integration.

e. Lack of ICT Pedagogy Professional: Nigeria lack manpower in this aspect, professional that can effectively train teachers on the use of Computer education for teaching and learning. As well as develop software which are compatible with the various curriculum.

f. Interest on the part of School-heads: School heads interest is important in the actualization of this programme. In that they will make the teachers take serious the training and implement what is learnt. Where they are not interested, the programme might face serious problem. 


\section{APPROACHES TO COMPUTER EDUCATION INTEGRATION IN TEACHER EDUCATION HUMAN CAPACITY BUILDING AND SUSTAINABILITY}

These are different methods in which Computer education can be integrated into teacher education, which is determined by the level of technological development attained or the level of technological development a nation intend to achieve. Each of these approaches also requires different educational policy directives, models and practice. These approaches according to $\mathrm{Ng}$, Mlao and Lee (2010) are:

1. The technology literacy approach. This is the simplest, its policy goals is to prepare students, citizens and the workforce that is capable of using Computer education to support social development and improve economic productivity. The programs that are coordinated with this policy aim are to develop teacher's skills in the use of Computer education tools in delivering the standard school curriculum.

Such teacher would know how, where and when (and when not) to use technology for classroom activities and presentations for management tasks, to acquire additional subject matter and pedagogical knowledge in support of their own professional developments.

2. The knowledge creation approach. It is the most complex approach. The policy goal is to increase civic participation, cultural creativity and a workforce that is continually engaged in knowledge creation, innovation and participation in the learning society. Thus, the curriculum goes beyond a focus on knowledge of school subjects to explicitly include the $21^{\text {st }}$ century skills that are needed to create new knowledge and engage in lifelong learning i.e the ability to collaborate, communicate, create, innovate and think critically. The programme under this approach would coordinate the teachers increasingly sophisticated professional skills with the pervasive use of technology to support students who are creating knowledge products and who are engaged and managing their own learning goals and activities. This takes place within a school. That is, the school itself becomes a continuously improving learning organization. In this context, teachers both model the learning process for students and serves as model learner through their own ongoing professional development.

3. The knowledge Deeping approach. This has impact on learning. Its policy goals is to increase the ability of learners, citizens and the workforce to knowledge ,to add value to society and the economy by applying knowledge to solve complex, real-world problem, such as those related to the environment, for security, health and conflict resolution. This policy goal requires curriculum change to emphasize depth of subject matter understanding and application. Under this approach, teachers will need to develop skills in the use of more sophisticated methodologies and technologies that will enable them to serve as a guide and manager of learning environment and enable students to engage in extended, collaborative project-based learning activities.

\section{CONCLUSION}

Levels of development attained by any nation determine if the nation is developed, developing and or under-developed. For Nigeria to advance to be addressed as developed nation, technology development of her workforce especially the teachers is required. This is because teachers are known the world over as nation builders; therefore, Computer education integration into teacher education is imperative. To achieve this, all education stakeholders are 
required to collaborate with government to proffer solution on how best this important national development need can be met.

\section{Recommendations}

a) There should be curriculum review as to integrate Computer education into teacher education curriculum

b) Compulsorily, teachers should be trained in the use of Computer education in teaching.

c) Leaders at all levels of education should be trained in the use of Computer education.

d) There should be collaboration between all the education stakeholders in the provision of Computer education.

e) There is need for urgent improvement of power supply.

f) Computer education should be incorporated into teacher training institutions.

\section{References}

[1] Adams M. W. (2006). "The Future of sustainability: Re-thinking Environment and Development in the $21^{\text {st }}$ century".

[2] Agabi O. G. (2008), Introducing educational planning, Port Harcourt. International Centre for Educational services Capacity Building for ICT in Education (2010) ICT in secondary education in the pacific region: status, trends and prospects. Retrieved 24 August 2011, from http://www.digital-review.org/uploads/files/pdf/2009-2010/capacity-building. pdf.

[3] Brundtland (1987). Economics development, $2^{\text {nd }}$ edition. Basingstoke: Macmillan. ISBN 033722280

[4] Bulus I., Mai I. (2006). Introduction to Current Practices in Education. ITF Press, Miango Road Jos Nigeria.

[5] Carlson S., Gadio C. (2002). Teacher professional development in the use of technology. 2011 from: http://porte.unsco.org/ic/en/ev/phi-URI.ID=22984\&URI.DO=DO.

[6] UNISCO Bangkok. (2004). Integrating ICTs into education. Lessons learned. Retrieved August 2011.

[7] Ng Wai-kong, Fengchun Mlao, Molly Lee (2010). Capacity building for ICT integration in Education http://digital.review.org/uplands/files/pdf/2009-DON/Capacity-building.pdf

[8] Okoro S. (2010). "Qualitative Universal Basic Education through Structural Innovation in Nigeria", Journal of Childhood and Primary Education, 7(I).

[9] Ololube A. C. Ubogu, A. Ossai, A.G. (2006). ICT and distance education in Nigeria: A Review of literature and accounts. International Open and Distance (IODL) Symposium. 2.643-655.Retrived 2nd of August, 2011.http//www.iodl.uk/public/itbook/kintns.htm.

[10] Otta K. (2003). “The case for strong sustainability". Greifswald's Environment Ethics: Steinbecker Verlag. ISBN 3931483320. Retrieved on: 2009-02-16. Parliamentary office of Science and Technology (2006).

[11] Dennis Agama Eka, International Letters of Social and Humanistic Sciences 8(2) (2014) 170-182. 
[12] Nayereh Shahmohammadi, International Letters of Social and Humanistic Sciences 8(2) (2014) 183-191.

[13] Godwin E. Itua, International Letters of Social and Humanistic Sciences 8(3) (2014) 200-207.

[14] Rowland U. Aleshi, Clementina N. Iloh, International Letters of Social and Humanistic Sciences 8(3) (2014) 208-216.

[15] Hannatu Abdullahi, International Letters of Social and Humanistic Sciences 8(3) (2014) 217-223.

[16] Fowoyo Joseph Taiwo, International Letters of Social and Humanistic Sciences 8(3) (2014) 244-251.

[17] Abdulrahaman W. Lawal, International Letters of Social and Humanistic Sciences 3 (2014) 53-59.

[18] Alaba E. Dare, International Letters of Social and Humanistic Sciences 3 (2014) 73-79.

[19] Grema Maina Bukar, Yohanna A. Timothy, International Letters of Social and Humanistic Sciences 4 (2014) 9-21.

[20] M. N. Modebelu, F. K. Igwebuike, International Letters of Social and Humanistic Sciences 4 (2014) 40-48.

[21] Akor Isaiah Akem, Victor Tavershima Ukeli, International Letters of Social and Humanistic Sciences 4 (2014) 49-59.

[22] Sule Maina, International Letters of Social and Humanistic Sciences 4 (2014) 87-96.

[23] Nwachukwu Uche Emma, International Letters of Social and Humanistic Sciences 5 (2014) 1-12.

[24] Peace Ebele Ilechukwu Chukwbikem, International Letters of Social and Humanistic Sciences 8(1) (2014) 1-17.

[25] Odo John Ogar, International Letters of Social and Humanistic Sciences 8(1) (2014) 28-33.

[26] Halima Sidi Bamall, International Letters of Social and Humanistic Sciences 8(1) (2014) 50-55.

[27] Elizabeth Morenikeji Titilayo Adediran, Albert Oluyomi Kehinde, International Letters of Social and Humanistic Sciences 8(1) (2014) 66-75.

[28] S. A. Kazeem, K. Y. Balogun, International Letters of Social and Humanistic Sciences 8(2) (2014) 108-119.

[29] Nneka Rita Udoye, Victor Etim Ndum, International Letters of Social and Humanistic Sciences 8(2) (2014) 130-139.

[30] Sanusi L. Sa'adatu, International Letters of Social and Humanistic Sciences 8(2) (2014) 140-147.

[31] Benedicta Ehi Momodu, International Letters of Social and Humanistic Sciences 13 (2014) 64-70.

[32] Adebowale Adeyemi-Suenu, International Letters of Social and Humanistic Sciences 13 (2014) 89-94. 
[33] Adebowale Adeyemi-Suenu, International Letters of Social and Humanistic Sciences 14 (2014) 1-6.

[34] Roghaieh Fathi, International Letters of Social and Humanistic Sciences 19 (2014) 24-34.

[35] Zahra Karami Baghteyfouni, Mehri Raoufi, Mahnaz Asadihaghighat, Hamidreza Mahmodian, Mohamad Khaledian, International Letters of Social and Humanistic Sciences 20 (2014) 1-8. 